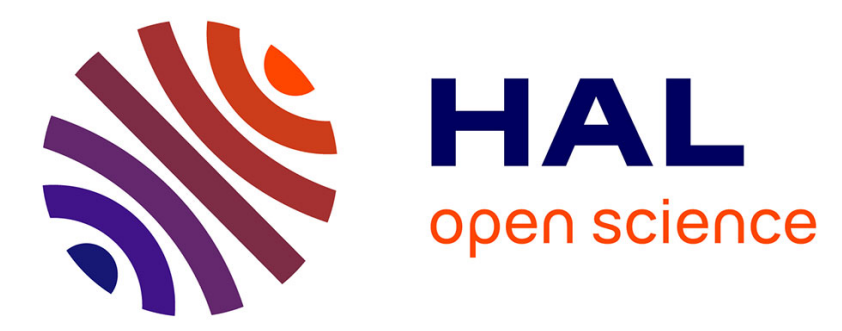

\title{
Estimation of pre-eruptive magmatic water fugacity in the Phlegrean Fields, Naples, Italy
}

\author{
Alessandro Fabbrizio, Bruno Scaillet, Michael R. Carroll
}

\section{To cite this version:}

Alessandro Fabbrizio, Bruno Scaillet, Michael R. Carroll. Estimation of pre-eruptive magmatic water fugacity in the Phlegrean Fields, Naples, Italy. European Journal of Mineralogy, 2009, 21 (1), pp.107116. insu-00372521

\section{HAL Id: insu-00372521 https://hal-insu.archives-ouvertes.fr/insu-00372521}

Submitted on 16 Oct 2009

HAL is a multi-disciplinary open access archive for the deposit and dissemination of scientific research documents, whether they are published or not. The documents may come from teaching and research institutions in France or abroad, or from public or private research centers.
L'archive ouverte pluridisciplinaire HAL, est destinée au dépôt et à la diffusion de documents scientifiques de niveau recherche, publiés ou non, émanant des établissements d'enseignement et de recherche français ou étrangers, des laboratoires publics ou privés. 


\title{
Estimation of pre-eruptive magmatic water fugacity in the Phlegrean Fields, Naples, Italy
}

\author{
Alessandro Fabbrizio ${ }^{1, *}$, Bruno Scaillet ${ }^{2,3}$ and Michael R. Carroll ${ }^{4}$ \\ ${ }^{1}$ Institute for Mineralogy and Petrology, ETH Zürich, Clausiusstrasse 25, 8092 Zürich, \\ Switzerland \\ ${ }^{2}$ Université d’Orléans, Institut des Sciences de la Terre d’Orléans, UMR 6113, 45067 \\ Orléans, France \\ ${ }^{3}$ CNRS/INSU, Institut des Sciences de la Terre d’Orléans, UMR 6113, 45067 Orléans, \\ France \\ ${ }^{4}$ Dipartimento di Scienze della Terra, Università di Camerino, Camerino 62032, Italy
}

\begin{abstract}
We estimated the water fugacity $\left(f \mathrm{H}_{2} \mathrm{O}\right)$ in the trachytic magma of Phlegrean Fields using the biotite-magnetite-sanidine equilibrium. We confirm that the partly ionic model is the most appropriate to estimate annite activity ( $a_{\text {annite }}$ ) for the experimental biotite. Crystallization experiments were carried out on a representative sample of trachytic Breccia Museo eruption, Naples, Italy. Experiments were performed in the temperature and pressure range of 725-870 ${ }^{\circ} \mathrm{C}$ and 50-200 MPa, and redox conditions ranging from NNO (nickel-nickel oxide) +1 $( \pm 0.2)$ to FMQ (fayalite + magnetite + quartz). Most experiments were done under conditions of $\mathrm{H}_{2} \mathrm{O}$ saturation $\left(P_{\text {water }}=P_{\text {total }}\right)$. Few experiments were done using a mixed $\mathrm{H}_{2} \mathrm{O}-\mathrm{CO}_{2}$ fluid phase. The pre-eruptive $\mathrm{fH}_{2} \mathrm{O}$ of the Phlegrean Fields magma is estimated at 735 bars, which compares well with available melt inclusion constraints. Our results confirm that this geohygrometer can be used in any magmatic systems bearing the worked assemblage.
\end{abstract}

Key-words: crystallization experiments, geohygrometer, trachytic magmas, water fugacity.

\section{Introduction}

The magmatic system of Phlegrean Fields, Naples, Italy, is an active volcanic field as demonstrated by the AD 1538 Monte Nuovo eruption, by bradyseismic crises in 1969-1972 and 1982-1984, and by widespread fumarolic and thermal springs activity (e.g., Armienti et al., 1983; Orsi et al., 1996; De Vita et al., 1999). These observations in conjunction with the extreme urbanization of the volcanic area (the area of the Phlegrean Fields caldera is inhabited by about 1.5 million people) indicate that the volcanic risk is very high. In an area with such characteristics, the definition of pre-eruptive conditions is crucial for understanding the behaviour of the system. Water is the most abundant volatile component in many magmatic systems, it can influence eruption style, magma physical properties and mineral stabilities. The abundance (or activity) of water can be estimated using a variety of approaches, including 
melt inclusion studies, phase equilibrium constraints, or devolatilisation equilibria involving hydrous phases.

The reaction:

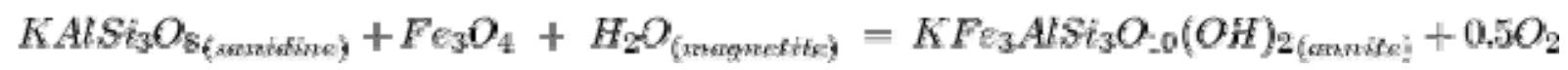
was used by Wones \& Eugster (1965) to estimate magmatic $f \mathrm{H}_{2} \mathrm{O}$ during crystallization, and the empirical relationship:

$\log f \mathrm{H}_{2} \mathrm{O}=74097 T^{2}+4.25+0.5 \log g \mathrm{O}_{2}$

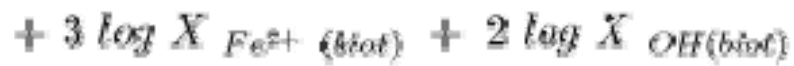

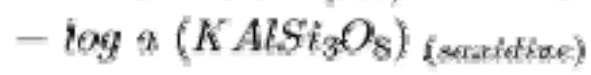

$-\log a\left(\mathrm{Feg}_{\mathrm{g}} \mathrm{O}_{4}\right)$ (meesgraetife)

was applied in granitic (Czamanske \& Wones, 1973) and phonolitic systems (Wolff \& Storey, 1984; Ablay et al., 1995; Fabbrizio et al., 2006) to estimate $f \mathrm{H}_{2} \mathrm{O}$.

We present new experimental data on trachytic melts saturated with biotite, magnetite and sanidine at water fugacities of 50-200 MPa $\left(P_{\text {water }}=50-200 \mathrm{MPa}\right)$. The new experimental data allow us to confirm that the model proposed by Czamanske \& Wones (1973) of annite activity ( $a_{\text {annite}}$ ) is the most appropriate for the experimental biotite. The results are used to evaluate pre-eruptive water fugacities in the trachytic magma from the Phlegrean Fields. As reported in Fabbrizio et al. (2006) we can use this geohygrometer to estimate pre-eruptive water fugacities in any magmatic (e.g., Fish Canyon Tuff, Bishop Tuff Rhyolite, Montaña Blanca) and metamorphic (e.g., metamorphic rocks from Au Sable) system bearing the worked assemblage.

\section{Experimental method}

\section{Starting material}

The experiments (Table 1) were done using a natural trachyte sample. It is from the same material used by Fabbrizio \& Carroll (2008) to determine phase equilibria of Phlegrean Fields trachytes; the major element composition is given in Table 2. This trachyte contains up to 30 \% by volume of crystals (Fulignati et al., 2004). K-feldspar (Kfs) is the dominant phenocryst with subordinate plagioclase, clinopyroxene, biotite and magnetite in order of decreasing abundance; apatite and titanite occur as accessory phases (Fulignati et al., 2004). Samples of 
the natural material were ground under acetone with an agate mortar and pestle to a grain size of 30-50 $\mu \mathrm{m}$ and this powder was used as the starting material for all experiments.

\section{Methods}

The powdered starting material was loaded together with a known amount of distilled water into $\mathrm{Au}$ capsules and the capsules were welded shut. Weighing during preparation of the capsule, before and after welding provided a check that no water was lost during the welding process. Welded capsules were placed in a drying oven at $110^{\circ} \mathrm{C}$ to check for leaks before they were used in experiments. Most experiments were done under conditions of $\mathrm{H}_{2} \mathrm{O}$ saturation $\left(P_{\text {water }}=P_{\text {total }}\right)$ where the amount of water needed to achieve $\mathrm{H}_{2} \mathrm{O}$ saturation was estimated from the water solubility data of Carroll \& Blank (1997). Typical runs had no more than $\sim 5 \mathrm{wt}$ \% excess fluid in order to minimize possible compositional changes due to solubility of the silicate components (e.g., alkalies) in the fluid at elevated $P$ and $T$. Two experiments were done using a mixed $\mathrm{H}_{2} \mathrm{O}-\mathrm{CO}_{2}$ fluid phase adding silver oxalate (as source of $\mathrm{CO}_{2}$ ) to these samples in sufficient quantity to reduce the water activity to 0.9 (Table 1 ).

\section{Oxygen fugacity}

Oxygen fugacity $\left(\mathrm{fO}_{2}\right)$ in the experiments at nickel-nickel oxide (NNO) +1 was controlled by either the intrinsic oxygen fugacity of the Ni-rich Nimonic 105 alloy of the pressure vessel or by the $\mathrm{H}_{2}$ fugacity ( $f \mathrm{H}_{2}$ ) of the fluid pressure medium (deionized water). Using the Ni-Pd$\mathrm{NiO}$ sensor method of Taylor et al. (1992) we have found that this design buffers the charges at an $f \mathrm{O}_{2}$ of 0.8-1.3 log unit above the Ni-NiO buffer curve (Di Matteo et al., 2004). In the QFM runs the $f \mathrm{H}_{2}$ was continuously read with Shaw membranes connected to transducers, with an uncertainty in $f \mathrm{H}_{2}$ of $\pm 0.02 \mathrm{MPa}$ at a level of $0.3-0.4 \mathrm{MPa}$ for run durations of 10 days (Scaillet \& Evans, 1999).

In the CSPV, variations in $\mathrm{H}_{2}$ pressures were always < $0.03 \mathrm{MPa}$ (Schmidt et al., 1995). Oxygen fugacity, for experiments in which water activity $\left(a \mathrm{H}_{2} \mathrm{O}\right)$ was varied by the addition of $\mathrm{CO}_{2}$ to the charges, can be evaluated using the following simple relationship (Scaillet \& Evans, 1999):

$\log f \mathrm{O}_{2}=\log 3 \mathrm{O}_{2} \operatorname{sat}-2 \log X\left(\mathrm{H}_{2} \mathrm{O}\right)$ 
where $f \mathrm{O}_{2}$ sat is the corresponding $f \mathrm{O}_{2}$ at water saturation $\left[X\left(\mathrm{H}_{2} \mathrm{O}\right)=1\right]$ at a given temperature and $X\left(\mathrm{H}_{2} \mathrm{O}\right)$ is the mole fraction of $\mathrm{H}_{2} \mathrm{O}$ in the starting fluid. For $X\left(\mathrm{H}_{2} \mathrm{O}\right)=0.9$, the decrease in $f \mathrm{O}_{2}$ is at best 0.1 log units, assuming ideal mixing between $\mathrm{CO}_{2}$ and $\mathrm{H}_{2} \mathrm{O}$. Further information about $f \mathrm{O}_{2}$ can be found in Shaw \& Wones (1963), Burnham et al. (1969), Robie et al. (1979) and Pownceby \& O’Neill (1994).

\section{Experimental apparatus and procedure}

Water saturated experiments were performed in three water-pressurized cold seal pressure vessels (CSPV, Nimonic 105), working vertically, at the Dipartimento di Scienze della Terra at University of Camerino (Italy). Experimental temperatures varied from 725 to $870{ }^{\circ} \mathrm{C}$ in the pressure range 50-200 MPa; run durations varied between 173 and $335 \mathrm{~h}$ depending on temperature, with longer duration at lower $T$ and lower $P$ conditions. Temperature was measured in the sample position with a sheathed type K thermocouple and is accurate to \pm 5 ${ }^{\circ} \mathrm{C}$; the temperature was checked against type $\mathrm{B} \mathrm{Pt}-\mathrm{Rh}$ thermocouple calibrated using the melting temperature of $\mathrm{Au}$. Pressure was recorded with a pressure transducer or Bourdon-tube pressure gauges, considered accurate to $\pm 2 \mathrm{MPa}$. Samples were quenched by removing the bomb from the furnace and immersing it in a high-pressure stream of compressed air. The samples cooled to below $500{ }^{\circ} \mathrm{C}$ within 3-4 min and to room temperature within $15 \mathrm{~min}$. The quench was isobaric because pressure was maintained during quenching by use of a large volume pressure reservoir and a hand operated pressure generator. Experimental conditions for each sample are reported in Table 1.

Additional experimental work was done at the ISTO-CNRS Orleans (France), using an internally heated pressure vessel(IHPV), working vertically, and fitted with a Shaw-type membrane for the control of $f \mathrm{H}_{2}$. Cold seal pressure vessels equipped with Shaw membranes, working horizontally, were also used. The pressure medium was a mixture of $\mathrm{Ar}+\mathrm{H}_{2}$ obtained either by sequential loading at room temperature (IHPV; see Scaillet et al., 1995) or by direct $\mathrm{H}_{2}$ diffusion across membrane (CSPV) under the experimental conditions (Schmidt et al., 1995). Total pressure was continuously monitored by transducers calibrated against a Heise Bourdon tube gauge with an uncertainty of 2 MPa (Scaillet \& Evans, 1999). In the IHPV, temperatures were recorded by three sheathed, type K thermocouples. In the CSPV, temperatures were recorded by an external unsheathed type $\mathrm{K}$ thermocouple. Temperature gradients in the hot spot zones were always $<3{ }^{\circ} \mathrm{C}$. The overall temperature uncertainty is \pm 5 
${ }^{\circ} \mathrm{C}$ (Schmidt et al., 1995). The experiment in the IHPV was terminated by switching off the power supply, resulting in temperature decreases of about $400{ }^{\circ} \mathrm{C}$ during the first $4 \mathrm{~min}$. No isobaric quench was carried out, and total pressure dropped by about half of its initial value during cooling in the IHPV. One condition was explored $\left(800^{\circ} \mathrm{C}, 150 \mathrm{MPa}, f \mathrm{O}_{2}=\mathrm{QFM}\right)$. Runs in the CSPV were ended by removing the vessel from the furnace with quench rates similar to those of the IHPV. No isobaric quench was carried out, and total pressure dropped by about $1 / 3$ of its initial value during cooling in the CSPV.

However, in both IHPV and CSPV runs, the pressure decrease reached at the glass transition temperature ( $\mathrm{ca} .550{ }^{\circ} \mathrm{C}$ for trachytic melts) is within $15 \%$ of the starting value. A total of two pressures was explored (150 and $200 \mathrm{MPa})$ at temperature of $800^{\circ} \mathrm{C}$ and $f \mathrm{O}_{2}=\mathrm{QFM}$. Run durations for experiments in the IHPV and in the CSPV varied between 173 and $209 \mathrm{~h}$ depending on the choice of experimental conditions (Table 1). After the quench, capsules were weighed to verify that they had remained sealed during the experiment and then were opened. Charges which did not fizz when pierced or otherwise indicated $\mathrm{H}_{2} \mathrm{O}$ loss during the experiment (weight change) were discarded.

After removing the silicate material from the capsules several fragments from each sample were mounted in epoxy resin and prepared as polished thin sections for petrographic and electron microprobe analysis.

\section{Analytical techniques}

Run products were characterized by reflected light microscopy, scanning electron microscopy and electron micro-probe methods. Major element analyses of minerals were carried out with a Cameca SX 50 microprobe at CNR-Istituto di Geologia Ambientale e Geoingegneria-Roma (Italy) and at CNRS-ISTO-BRGM-Orleans (France); analyses of the same samples with both instruments did not show any statistically significant variations in results. Analytical conditions for the electron microprobe were: accelerating voltage $15 \mathrm{kV}$, sample current 10 $\mathrm{nA}$, counting time of $15 \mathrm{~s}$ on peak for $\mathrm{Mg}, \mathrm{Al}, \mathrm{Ca}, \mathrm{Ti}, \mathrm{Mn}, \mathrm{Fe}$, of $30 \mathrm{~s}$ for $\mathrm{F}, \mathrm{Cl}$, and $\mathrm{S}$, and of $8 \mathrm{~s}$ for $\mathrm{Na}, \mathrm{K}$, and Si. Analyses used a focused beam (diameter 1-2 $\mu \mathrm{m}$ ) for minerals. For each experiment we attempted to obtain multiple analyses of the crystalline phases present, checking both rim and core compositions to look for any zoning whenever crystal size permitted. Analyses were obtained for multiple grains from different locations within the charge. No significant compositional variations were observed within single experiments. The 
experimental run conditions are listed in Table 1 and average analyses of biotite, magnetite and sanidine in each experiment are presented in Table 2.

\section{General observations}

A total of 23 experiments containing the biotite-magnetite-sanidine assemblage have been completed at pressures of 50-200 MPa, temperatures of $725-870{ }^{\circ} \mathrm{C}, f \mathrm{O}_{2}$ ranging from QFM to $\mathrm{NNO}+1$, at, or near, water saturation. All experiments were crystallization experiments (Fig. 1), which were heated to $\sim 925^{\circ} \mathrm{C}$, above the liquidus, for two hours to dissolve any inherited crystal, and then cooled isobarically to run conditions to optimize crystal growth. No restitic crystals were present in the final product, owing to the low viscosity of phonotrachytic melts which probably facilitates mineral dissolution and growth (Fabbrizio et al., 2006).

The presence of fluid inclusions (bubbles) trapped in glass was observed in most charges and taken as evidence of saturation of the melt with respect to a fluid phase under the experimental conditions. In addition to the systematic presence of bubbles, the presence of a fluid phase was also confirmed by small drops of water released from the capsules on opening, by hissing when the capsules contained $\mathrm{CO}_{2}$, and water loss on opening and heating at $110{ }^{\circ} \mathrm{C}$ shows presence of fluid phase (weight change). The crystallization experiments produced the following textural features: (1) homogeneous distribution of all phases present (glass + crystals + bubbles), (2) homogeneity of crystal sizes and euhedral shapes, (3) bubble sizes that were homogeneous in $\mathrm{CO}_{2}$-free experiments but more variable in $\mathrm{CO}_{2}$-bearing ones.

Crystalline phases identified in run products were K-feldspar, biotite, magnetite, clinopyroxene, plagioclase, apatite, titanite. The natural phase assemblage was successfully reproduced in most of the crystallization experiments. From the viewpoint of phase petrology, crystallization experiments gave results consistent with an overall close approach to bulk equilibrium. The compositions of product phases are homogeneous in a given charge. Solidsolution phases display continuous and smooth compositional changes with variations in the main intensive variables $T, a \mathrm{H}_{2} \mathrm{O}$ and $f \mathrm{O}_{2}$. 


\section{Silicate and oxide activities}

\section{Sanidine}

Table 2 shows alkali feldspar microprobe analyses and end member percentages. We have estimated sanidine activities graphically from the plot of Waldbaum \& Thompson's (1969) binary alkali feldspar data given by Carmichael et al. (1974). Most of our K-feldspars have activity between 0.6 and 0.8 (Table 3). The small variations in $\mathrm{KAlSi}_{3} \mathrm{O}_{8}$ activity, over the range of conditions investigated, does not significantly affect the calculation of $f\left(\mathrm{H}_{2} \mathrm{O}\right)$.

\section{Magnetite}

The reader should refer to Katsura et al., (1974), Woodland (1988) and Sack\& Ghiorso(1991) for the activity-composition relations for $\mathrm{Fe}_{3} \mathrm{O}_{4}-\mathrm{Fe}_{2} \mathrm{TiO}_{4}$ (magnetite-ülvospinel). In our work, magnetite activities calculated using a 4-oxygen structural formula and with the activitycomposition relations described in Fabbrizio et al. (2006) vary between 0.83 and 0.95 (Table 3).

\section{Annite}

The calculation of accurate biotite structural formula is crucial for the estimation of annite activity and thus for the calculation of $f \mathrm{H}_{2} \mathrm{O}$. As reported in Fabbrizio et al. (2006) the most important factors to determine are the $\mathrm{Fe}^{2+} / \mathrm{Fe}^{3+}, \mathrm{F} / \mathrm{OH}$ ratios, and possible additional substitutions (e.g., $\mathrm{Ti}^{4+}$ ). Additional difficulties come from electron microprobe analyses that do not yield measurements of $\mathrm{Fe}^{3+}$, and accurate estimation of $\mathrm{Fe}^{3+}$ contents using only charge balance are difficult due to possible non-stoichiometry associated with octahedral site vacancies (Deer et al., 1992). Figure 2 shows that natural and experimental biotite compositions are shifted towards the siderophyllite-eastonite join, in which a portion of iron can be present as $\mathrm{Fe}^{3+}$ substitution for $\mathrm{Al}$ in the octahedral site where octahedral $\mathrm{Fe}$ and $\mathrm{Mg}$ loss is balanced by a subsitution of Al for Si in the tetrahedral site. Several substitutions can occur in the octahedral sites complicating the crystallochemistry of biotite. Compositional variations include $\mathrm{Fe}^{2+}, \mathrm{Mg}, \mathrm{Fe}^{3+}, \mathrm{Ti}$, Tschermark exchange $\left(\mathrm{R}^{2+(\mathrm{VI})}+\mathrm{Si}^{4+(\mathrm{IV})}=\mathrm{Al}^{3+(\mathrm{VI})}+\right.$ $\mathrm{Al}^{3+(\mathrm{IV})}$ ), and vacancies. We have estimated $\mathrm{Fe}^{3+}$ contents using the normalization procedure of Dymek (1983). 
Values of $\mathrm{Fe}^{3+}$ obtained using this method are $<30 \%$ of the total $\mathrm{Fe}$, in keeping with the relatively reduced nature of the experimental runs. Fluorine was measured during microprobe analysis, and is found to fill $<25 \%$ of the $\mathrm{OH}^{-}$sites (Table 3). $\mathrm{Cl}^{-}$and $\mathrm{HS}^{-}$contents of the experimental biotites are negligible, and the hydroxyl sites not occupied by $\mathrm{F}$ are assumed to be filled with $\mathrm{OH}^{-}$. Complete calculated biotite formula for all of the experimental samples are given in Table 3.

Different equations were proposed to estimate annite activity (e.g., Wones \& Eugster, 1965; Mueller, 1972; Czamanske \& Wones, 1973; Bohlen et al., 1980). Annite activity can be calculated in the following ways:

$$
\begin{aligned}
& a_{\text {enzwite }}=F \varepsilon^{2+} /\left(F e^{2+}+M g\right) \\
& a_{\text {enwerte }}=\left[\mathrm{Fe}^{2+}\left[\left(\mathrm{Fe}^{2+}+\mathrm{Mg}\right)\right]^{3}\right. \\
& a_{\text {enzwite }}=\left(X_{F^{2+}}\right)^{3} \\
& a_{\text {trwaite }}=\left(X_{F \mathrm{E}^{2}+}\right)^{3}\left(X_{O H}\right)^{2} \\
& a_{\text {ezmite }}=\left(X_{N}\right)\left(X_{F^{2}+1}\right)^{3}\left(X_{A l}\right)\left(X_{n i}\right)^{3}\left(X_{\sigma H}\right)^{2} /\left(X_{A l}^{0}\right)\left(X_{s i}^{0}\right)^{3}
\end{aligned}
$$

All of these models are discussed in Fabbrizio et al. (2006).

\section{Discussion}

It should be clear from the preceding presentation of our experimental data that the major obstacle in using the biotite-magnetite-sanidine equilibrium to estimation of magmatic water activities is the choice of a model for annite activity. We have used the molecular model (Eq. (4)) of Wones \& Eugster (1965), the partly ionic model (Eq. (7)) of Czamanske \& Wones (1973), and the complete ionic model (Eq. (8)) of Bohlen et al. (1980) to estimate annite activities and these different annite activities have been used to calculate $f \mathrm{H}_{2} \mathrm{O}$ of experimental samples via Eq. (2), substituting the appropriate terms for annite activity. Calculated annite activities, and estimated water fugacities using each of the annite activity models are presented in Table 3, along with the calculated water fugacities for experimental samples, calculated using a Modified Redlich Kwong (MRK) equation of state (EOS) (Holloway, 1981). 
The molecular model significantly overestimates $f \mathrm{H}_{2} \mathrm{O}$ in every case (Fig. 3). This overestimation is a direct consequence of the model treating the biotite as a pure phlogopiteannite solid solution. The result is that components not on the phlogopite-annite join, which

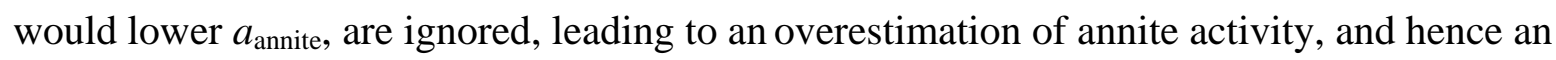
overestimation of $f \mathrm{H}_{2} \mathrm{O}$. By contrast the complete ionic model underestimates $f \mathrm{H}_{2} \mathrm{O}$ relative to the calculated $f \mathrm{H}_{2} \mathrm{O}$ in each case. This model assumes ideal mixing of the additional components in the biotite, treating them as dilutents, which diminish the annite component of the biotite. The underestimation of $a_{\text {annite }}$ using this model indicates that mixing of the additional components is not ideal, as indicated by Bailey (1984). Bohlen et al. (1980) suggest using these models to obtain an upper and lower limiting $f \mathrm{H}_{2} \mathrm{O}$ 's for biotite-magnetitesanidine assemblages.

Given the data obtained from the hydrothermal experiments this would appear a reasonable approach for natural biotites with complex substitutions, and/or containing large amounts of other elements, such as $\mathrm{Cr}, \mathrm{Li}, \mathrm{Mn}$ in the octahedral site. An Accurate estimate of the $\mathrm{Fe}^{3+}$ content, and the low amounts of $\mathrm{F}$ and $\mathrm{Cl}$ in the $\mathrm{OH}$ sites, enable an accurate estimation of $a_{\text {annite }}$ from the partly ionic model (Eq. (7)) of Czamanske \& Wones (1973). Estimates of $f$ $\mathrm{H}_{2} \mathrm{O}$ obtained using this activity model closely approximate the values calculated using a Modified Redlich Kwong equation of state for $\mathrm{H}_{2} \mathrm{O}$ fugacities in the experiments (Holloway, 1981). The pre-eruptive $f \mathrm{H}_{2} \mathrm{O}$ of the Phlegrean Fields magma can therefore be estimated using the annite activity model of Czamanske \& Wones (1973). Using the annite activity model of Czamanske \& Wones (1973) the range of $f \mathrm{H}_{2} \mathrm{O}$ which have been tested in the experiments for the Phlegrean Fields is 309-1646 bars. Considering the composition of the natural biotite (Table 3) the $f \mathrm{H}_{2} \mathrm{O}$ of the Phlegrean Fields magma chamber is estimated at $\sim 735$ bars (unfortunately we do not know the dissolved $\mathrm{H}_{2} \mathrm{O}$ and $\mathrm{CO}_{2}$ in a melt inclusion, consequently, our estimate is just a minimum estimate). Ablay (1997) estimated, from melt inclusion, water fugacities values for the Montaña Blanca in the range 640-1340 bars. More recently Fabbrizio et al. (2006) calculated water fugacities, for the Montaña Blanca phonolitic system, to be in the range 195-1535 bars. Estimates from this study are comparable with the range of estimates provided by Fabbrizio et al. (2006) and by Ablay (1997), and have shown that:

1. Of the annite activity models that have been proposed, the activity model of Czamanske \& Wones (1973) provides the most accurate estimates of pre-eruptive water fugacity. 
2. The molecular model of Wones \& Eugster (1965) and the total ionic model of Bohlen et al. (1980), provide respectively, the upper and the lower value in the estimate of water fugacities.

3. The results of these studies indicate that the pre-eruptive water fugacities of phonolitic and phonotrachytic magmatic systems can be variable with value ranging from 200 to 1650 bars. This range reflects differing magma storage depths or wide variations in the $\mathrm{CO}_{2} / \mathrm{H}_{2} \mathrm{O}$ ratio in the coexisting melt (gas phase), or possibly, the fact that biotite-melt equilibrium may change during magma decompression in which case the spread in water fugacity does not necessarily reflect different depths of magma storage. (Be aware however that biotite, as an hydrous mineral, may not be stable anymore at very low $f \mathrm{H}_{2} \mathrm{O}$ (as observed for amphibole although clearly biotite is less sensitive to change in $f \mathrm{H}_{2} \mathrm{O}$ than is amphibole)).

\section{Acknowledgements}

This manuscript is a part of the Ph.D. project of the first author; we wish to thank Dr. V. Di Matteo who provided the natural sample used for the experiments in this study, Marcello Serracino (University of Roma, CNR) and Olivier Rouer (CNRS, Orleans) for their technical support on the electron microprobes. We are grateful to Angelo Peccerillo for his editorial comments, to Malcolm Rutherford and to an anonymous reviewer who provided helpful comments. This work has been financially supported by the COFIN 04 INGV, FIRB and Dip. Prot. Civ. Italy. 


\section{References}

Ablay, G.J. (1997): Evolution of the Teide-Pico Viejo volcanic complex and magmatic system, Tenerife, Canary Islands. Unpublished PhD Thesis, University of Bristol, UK.

Ablay, G.J., Ernst, G.G.J., Marti, J., Sparks, R.S.J. (1995): The 2 ka subplinian eruption of Montaña Blanca, Tenerife. Bull. Volcanol., 57, 337-355.

Armienti, P., Barberi, F., Bizouard, H., Clochiatti, R., Innocenti, F., Metrich, N., Rosi, M., Sbrana, A. (1983): The Phlegrean Fields: magma evolution within a shallow chamber. $J$. Volcanol. Geother. Res., 17, 289-311. Bailey, S.W. (1984): Micas. Reviews in mineralogy. Mineralogical Society of America, Chantilly, Virginia, 584 p.

Bohlen, S.R., Peacor, D.R., Essene, E.J. (1980): Crystal chemistry of a metamorphic biotite and its significance in water barometry. Am. Mineral., 65, 55-62.

Burnham, C.W., Holloway, J.R., Davis, N.F. (1969): Thermodynamic properties of water to $1000{ }^{\circ} \mathrm{C}$ and 10000 bar. Geol. Soc. Am. Special Paper, 132, 1-96.

Carmichael, I.S.E., Turner, F.J., Verhoogen, J. (1974): Igneous Petrology. McGraw-Hill, New York.

Carroll, M.R. \& Blank, J.G. (1997): The solubility of $\mathrm{H}_{2} \mathrm{O}$ in phonolite melts. Am. Mineral., 82, 549-556.

Czamanske, G.K. \& Wones, D.R. (1973): Oxidation during magmatic differentiation, Finnmarka Complex, Oslo area, Norway: Part 2, the mafic silicates. J. Petrol., 14, 349-380

Deer, W.A., Howie, R.A., Zussman, J. (1992): An introduction to the rock forming minerals, second ed., Longman Scientific \& Technical, New York.

De Vita, S., Orsi, G., Civetta, L., Carandente, A., D’Antonio, M., Deino, A., Di Cesare, T., Di Vito, M.A., Fisher, R.V., Isaia, R., Marotta, E., Necco, A., Ort, M., Pappalardo, L., Piochi, M., Southon, J. (1999): The Agnano-Monte Spina eruption (4100 years BP) in the restless Campi Flegrei caldera (Italy). J. Volcanol. Geother. Res., 91, 269-301.

Di Matteo, V., Carroll, M.R., Behrens, H., Vetere, F., Brooker, R.A. (2004): Water solubility in trachytic melts. Chem. Geol., 213, 187-196.

Droop, G.T.R. (1987): A general equation for estimating $\mathrm{Fe}^{3+}$ concentrations in ferromagnesian silicates and oxides from microprobe analyses, using stoichiometric criteria. Mineral. Mag., 51, 431-435.

Dymek, R.F. (1983): Titanium, aluminum, and interlayer cation substitutions in biotite from high-grade gneisses, West Greenland. Am. Mineral., 68, 880-899.

Fabbrizio, A. \& Carroll, M.R. (2008): Experimental studies of the differentiation process and pre-eruptive conditions in the magmatic system of Phlegrean Fields (Naples, Italy). $J$. Volcanol. Geother. Res., 171, 88-102. 
Fabbrizio, A., Rouse, P.J., Carroll, M.R. (2006): New experimental data on biotite + magnetite + sanidine saturated phonolitic melts and application to the estimation of magmatic water fugacity. Am. Mineral., 91, 1863-1870.

Fulignati, P., Marianelli, P., Proto, M., Sbrana, A. (2004): Evidences for disruption of crystallizing front in a magma chamber during caldera collapse: an example from the Breccia Museo unit (Campanian Ignimbrite eruption, Italy). J. Volcanol. Geother. Res., 133, 141-155.

Holloway, J.R. (1981): Volatile interactions in magmas - Thermodynamics of minerals and melts, Springer-Verlag, New York, 273-293.

Katsura, K., Wakihara, M., Hara, S.I., Sugihara, T. (1974): Some thermodynamic properties in spinel solid solutions with the $\mathrm{Fe}_{3} \mathrm{O}_{4}$ component. J. Sol. St. Chem., 13, 107-113.

Melluso, L., Morra, V., Perrotta, A., Scarpati, C., Adabbo, M. (1995): The eruption of the Breccia Museo (Campi Flegrei, Italy): fractional crystallization processes in a shallow, zoned magma chamber and implications for the eruptive dynamics. J. Volcanol. Geother. Res., 68, 325-339.

Mueller, R. (1972): On the stability of biotite. Am. Mineral., 57, 300-316.

Orsi, G., De Vita, S., Di Vito, M. (1996): The restless, resurgent Campi Flegrei caldera (Italy): constraints on its evolution and configuration. J. Volcanol. Geother. Res., 74, 179214.

Pownceby, M.I. \& O’Neill, H.St.C. (1994): Thermodynamic data from redox reactions at high temperatures. III. Activity-composition relations in Ni-Pd alloys from EMF measurements at 850-1250 K, and calibration of the $\mathrm{NiO}+\mathrm{Ni}-\mathrm{Pd}$ assemblage as a redox sensor. Contrib. Mineral. Petrol., 116, 327-339.

Robie, R.A., Hemingway, B.S., Fisher, J.R. (1979): Thermodynamic properties of minerals and related substances at $298.15 \mathrm{~K}$ and 1 bar $\left(10^{5}\right.$ pascals $)$ pressure and at higher temperature. US Geol. Surv. Bull., 1452.

Sack, R.O. \& Ghiorso, M.S. (1991): An internally consistent model for the thermodynamic properties of Fe-Mg-titanomagnetite-aluminate spinels. Contrib. Mineral. Petrol., 106, 474505.

Scaillet, B. \& Evans, B.W. (1999): The 15 June 1991 eruption of Mount Pinatubo. I. Phase equilibria and pre-eruption $P-T-f \mathrm{O}_{2}-f \mathrm{H}_{2} \mathrm{O}$ conditions of the dacite magma. J. Petrol., 40, 381-411.

Scaillet, B., Pichavant, M., Roux, J. (1995): Experimental Crystallization of Leucogranite Magmas. J. Petrol., 36, 663-705.

Schmidt, B.C., Scaillet, B., Holtz, F. (1995): Accurate control of $f \mathrm{H}_{2}$ in cold seal pressure vessels with the shaw membrane technique. Eur. J. Mineral., 7, 893-903.

Shaw, H.R. \& Wones, D.R. (1963): Fugacity coefficients for hydrogen gas between $0{ }^{\circ} \mathrm{C}$ and $1000{ }^{\circ} \mathrm{C}$, for pressures to $3000 \mathrm{~atm}$. Am. J. Sci., 262, 918-929. 
Stormer, J.C. (1983): The effects of recalculation on estimates of temperature and oxygen fugacity from analyses of multi-component iron-titanium oxides. Am. Mineral., 68, 586-594.

Taylor, J.R., Wall, V.J., Pownceby, M.I. (1992): The calibration and application of accurate redox sensors. Am. Mineral., 77, 284-295.

Waldbaum, D.R. \& Thompson, J.B. (1969): Mixing properties of sanedine crystalline solutions: iv Phase diagrams from equations of state. Am. Mineral., 54, 1274-1298.

Wolff, J.A. \& Storey, M. (1984): The volatile component of some pumice-forming alkaline magmas from the Azores and Canary Islands. Contrib. Mineral. Petrol., 82, 66-74.

Wones, D.R. \& Eugster, H.P. (1965): Stability of biotite: experiment, theory and application. Am. Mineral., 50, 1228-1271.

Woodland, A.B. (1988): Fe-Ti and Fe-Al oxides as indicators of oxygen fugacity in rocks. PhD Thesis, Northwestern University, Evanston Illinois.

Woodland, A.B. \& Wood, B.J. (1994): $\mathrm{Fe}_{3} \mathrm{O}_{4}$ activities in Fe-Ti spinel solid solutios. Eur. J. Mineral., 6, 23-37. 


\section{Figures}
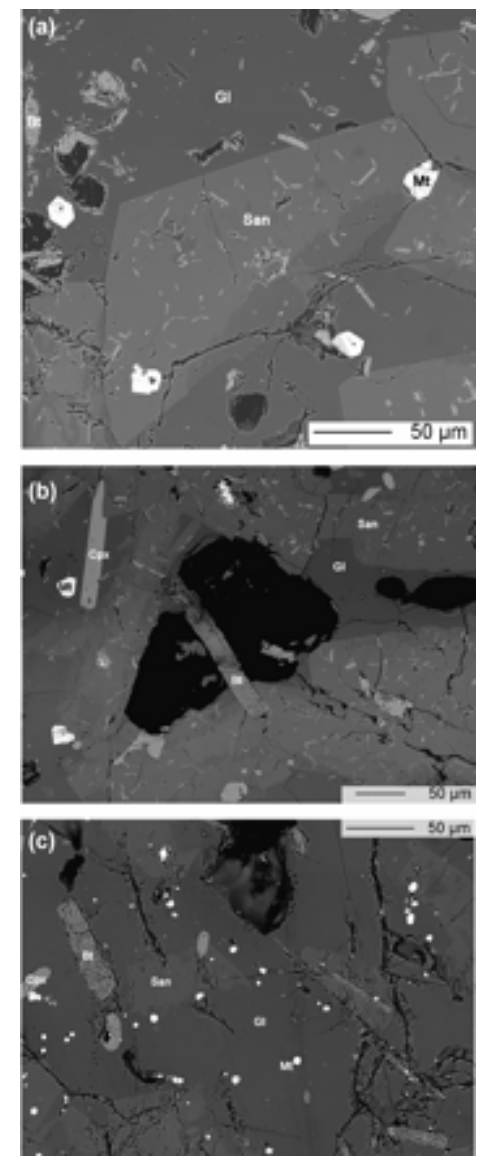

Fig. 1. Back-scattered electron images of selected experimental runs. (a) Run PR38I (800 ${ }^{\circ} \mathrm{C}$, $200 \mathrm{MPa}$ ). (b) Run PR38B (825 $\left.{ }^{\circ} \mathrm{C}, 150 \mathrm{MPa}\right)$. (c) Run PR38T (870 $\left.{ }^{\circ} \mathrm{C}, 100 \mathrm{MPa}\right)$. Gl (glass), San (sanidine), Bt (biotite), Mt (magnetite), Cpx (clinopyroxene). All minerals are euhedral and unzoned demonstrating a close approach to an equilibrium condition. 


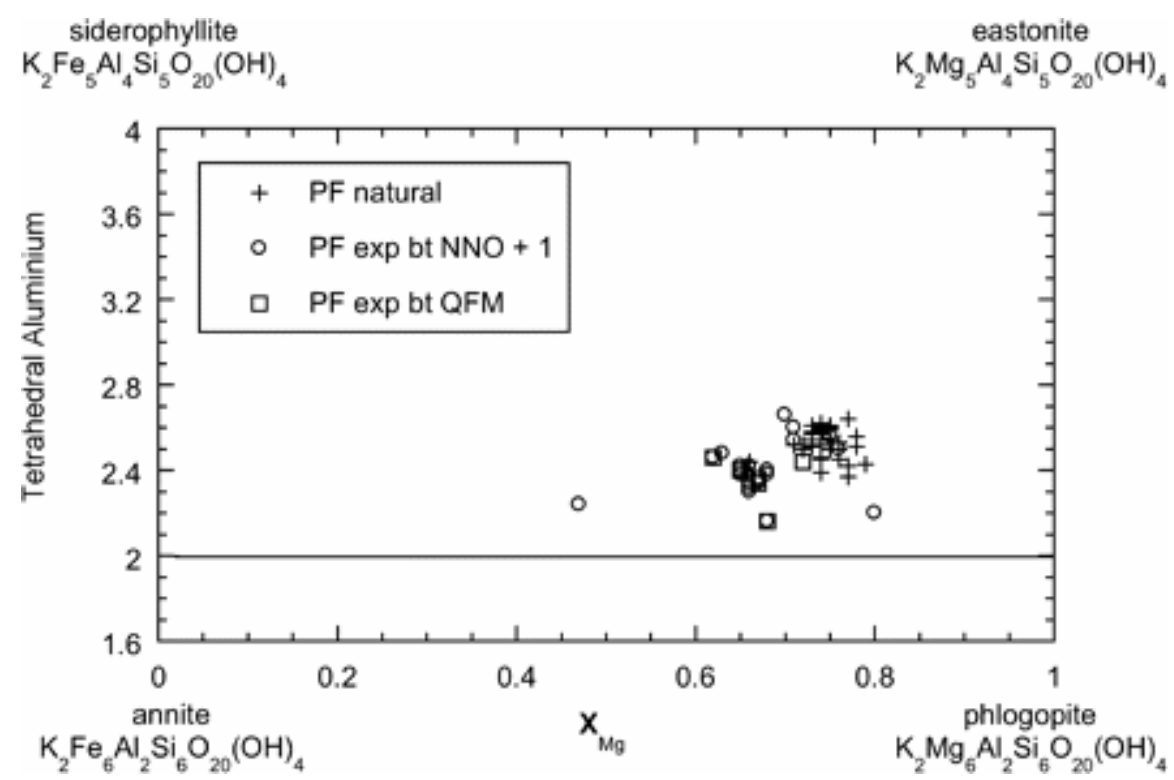

Fig. 2. Classification diagram of biotite as a function of $\boldsymbol{X}_{\mathrm{Mg}}$. The composition of experimental and natural biotites is illustrated in terms of the end-members annitephlogopite-siderophyllite-eastonite. It shows that natural and experimental biotites are dominantly a phlogopite-annite mixture. Although biotites fall close to annite-phlogopite join, their compositions are slightly shifted towards the siderophyllite-eastonite join in which a portion of $\mathrm{Fe}$ can be present as $\mathrm{Fe}^{3+}$. Crosses, natural biotite from Phlegrean Fields. Circles, experimental biotite obtained with the Phlegrean Fields starting material at $f \mathrm{O}_{2}=\mathrm{NNO}+1$. Squares, experimental biotite obtained with the Phlegrean Fields starting material at $f \mathrm{O}_{2}=$ FMQ. Natural biotite data are taken from Armienti et al. (1983), Melluso et al. (1995), Orsi et al.(1995) and Civetta et al. (1997). 


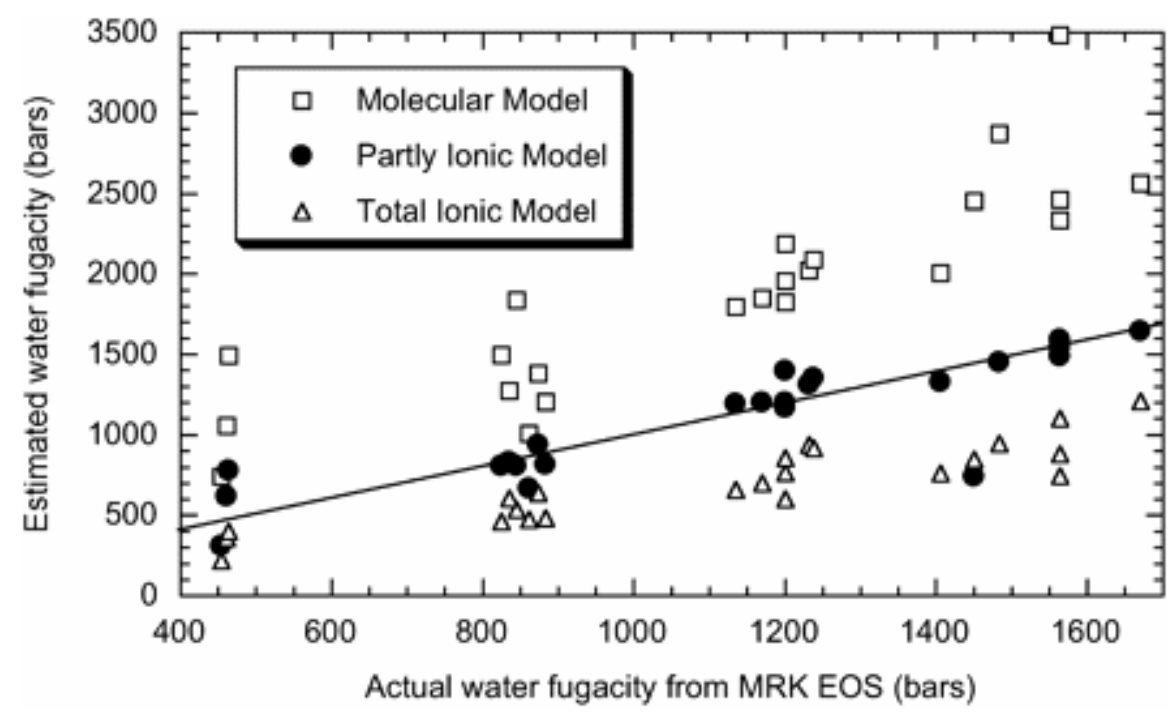

Fig. 3. Measured (experimental) water fugacities as a function of calculated water fugacities using a Modified Redlick Kwong (MRK) equation of state (EOS) (Holloway, 1981). Squares, estimated water fugacity using the annite activity model of Wones \& Eugster (1965). Circles, estimated water fugacity using the annite activity model of Czamanske \& Wones (1973). Triangles, estimated water fugacity using the annite activity model of Bohlen et al. (1980). Larger filled symbols indicate our preferred model; smaller open symbols indicate alternative models. The solid line represents the condition $Y=X$. 


\section{Tables}

Table 1. Experimental run conditions.

\begin{tabular}{|c|c|c|c|c|c|c|c|c|}
\hline Run & $\mathrm{fO}_{2}$ & $\begin{array}{l}P_{\text {total }} \\
\text { (MPa) }\end{array}$ & $\begin{array}{c}T \\
\left({ }^{\circ} \mathrm{C}\right)^{\mathrm{a}}\end{array}$ & $\begin{array}{l}f \mathrm{H}_{2} \mathrm{O} \\
(\mathrm{bar})^{\mathrm{b}}\end{array}$ & $\begin{array}{c}\log f \\
\mathrm{O}_{2}\end{array}$ & $\begin{array}{c}X \\
\left(\mathrm{H}_{2} \mathrm{O}\right)^{\mathrm{c}}\end{array}$ & $\begin{array}{l}\text { Run duration } \\
\text { (hours) }\end{array}$ & Run products \\
\hline $38 I$ & $\begin{array}{l}\mathrm{NNO}+ \\
1\end{array}$ & 200 & 800 & 1565 & -13.00 & 1 & 215 & Gl, Mt, Cpx, Bt, San \\
\hline $38 \mathrm{E}$ & $\begin{array}{l}\mathrm{NNO}+ \\
1\end{array}$ & 200 & 775 & 1516 & -13.34 & 1 & 262 & $\begin{array}{l}\text { Gl, Mt, Cpx, Bt, San, } \\
\text { Plg }\end{array}$ \\
\hline $38 \mathrm{~F}$ & $\begin{array}{l}\mathrm{NNO}+ \\
1\end{array}$ & 200 & 760 & 1485 & -13.68 & 1 & 256 & $\begin{array}{l}\text { Gl, Mt, Cpx, Bt, San, } \\
\text { Plg }\end{array}$ \\
\hline $38 \mathrm{X}$ & $\begin{array}{l}\mathrm{NNO}+ \\
1\end{array}$ & 200 & 745 & 1453 & -14.03 & 1 & 196 & Mt, Cpx, Bt, San, Plg \\
\hline $38 \mathrm{Z}$ & $\begin{array}{l}\mathrm{NNO}+ \\
1\end{array}$ & 200 & 725 & 1407 & -14.05 & 1 & 211 & Mt, Cpx, Bt, San, Plg \\
\hline 38B & $\begin{array}{l}\mathrm{NNO}+ \\
1\end{array}$ & 150 & 825 & 1233 & -.03 & 1 & 185 & Gl, Mt, Cpx, Bt, San \\
\hline $38 \mathrm{H}$ & $\begin{array}{l}\mathrm{NNO}+ \\
1\end{array}$ & 150 & 800 & 1203 & -13.43 & 1 & 215 & $\begin{array}{l}\text { Gl, Mt, Cpx, Bt, San, } \\
\text { Plg }\end{array}$ \\
\hline 380 & $\begin{array}{l}\mathrm{NNO}+ \\
1\end{array}$ & 150 & 775 & 1170 & -13.86 & 1 & 191 & Mt, Cpx, Bt, San, Plg \\
\hline $38 \mathrm{~N}$ & $\begin{array}{l}\mathrm{NNO}+ \\
1\end{array}$ & 150 & 750 & 1134 & -14.15 & 1 & 190 & Mt, Cpx, Bt, San, Plg \\
\hline $38 \mathrm{~T}$ & $\begin{array}{l}\mathrm{NNO}+ \\
1\end{array}$ & 100 & 870 & 883 & -12.41 & 1 & 185 & Gl, Mt, Cpx, Bt, San \\
\hline $38 \mathrm{~W}$ & $\begin{array}{l}\mathrm{NNO}+ \\
1\end{array}$ & 100 & 850 & 873 & -13.12 & 1 & 191 & Gl, Mt, Cpx, Bt, San \\
\hline $38 \mathrm{D}$ & $\begin{array}{l}\mathrm{NNO}+ \\
1\end{array}$ & 100 & 825 & 858 & -.30 & 1 & 189 & Mt, Cpx, Bt, San, Plg \\
\hline $38 \mathrm{P}$ & $\begin{array}{l}\mathrm{NNO}+ \\
1\end{array}$ & 100 & 800 & 842 & -14.00 & 1 & 190 & Mt, Cpx, Bt, San, Plg \\
\hline $38 \mathrm{~V}$ & $\begin{array}{l}\mathrm{NNO}+ \\
1\end{array}$ & 100 & 790 & 835 & -.00 & 1 & 190 & Mt, Cpx, Bt, San, Plg \\
\hline $38 \mathrm{M}$ & $\begin{array}{l}\mathrm{NNO}+ \\
1\end{array}$ & 100 & 775 & 825 & -14.00 & 1 & 189 & Mt, Cpx, Bt, San, Plg \\
\hline 384 & $\begin{array}{l}\mathrm{NNO}+ \\
1\end{array}$ & 50 & 870 & 466 & -12.43 & 1 & 192 & Gl, Mt, Cpx, Bt, San \\
\hline 385 & $\begin{array}{l}\mathrm{NNO}+ \\
1\end{array}$ & 50 & 840 & 461 & -13.02 & 1 & 192 & Mt, Cpx, Bt, San, Plg \\
\hline $38 \mathrm{~A}$ & $\begin{array}{l}\mathrm{NNO}+ \\
1\end{array}$ & 50 & 810 & 456 & -13.14 & 1 & 335 & Mt, Cpx, Bt, San, Plg \\
\hline 3823 & QFM & 200 & 800 & 1565 & -.80 & 1 & 185 & $\begin{array}{l}\text { Gl, Mt, Cpx, Bt, San, } \\
\text { Plg }\end{array}$ \\
\hline 3824 & $\mathrm{QFM}^{\mathrm{d}}$ & 200 & 800 & 1565 & -12.50 & 0.9 & 185 & $\begin{array}{l}\text { Gl, Mt, Cpx, Bt, San, } \\
\text { Plg }\end{array}$ \\
\hline 381 & QFM & 150 & 800 & 1238 & -13.48 & 1 & 209 & Mt, Cpx, Bt, San, Plg \\
\hline
\end{tabular}




\begin{tabular}{|c|c|c|c|c|c|c|c|c|}
\hline 382 & QFM & 150 & 798 & 1200 & -13.12 & 1 & 173 & Mt, Cpx, Bt, San, Plg \\
\hline 383 & $\mathrm{QFM}^{\mathrm{d}}$ & 150 & 798 & 1200 & -.12 & 0.9 & 173 & Mt, Cpx, Bt, San, Plg \\
\hline
\end{tabular}


Table 2. $\mathrm{SiO}_{2}$ and $\mathrm{TiO}_{2}$ abundances (XRF, wt.\%) ${ }^{*}$ for the starting Phlegrean Fields trachyte 38 and for mineral phases (EMPA) of experimental runs.

\begin{tabular}{|c|c|c|c|c|c|c|c|c|c|c|c|c|c|c|c|c|c|}
\hline Run & Phase & $\mathrm{SiO}_{2}$ & $\mathrm{TiO}_{2}$ & $\mathrm{Al}_{2} \mathrm{O}_{3}$ & $\mathrm{FeO}$ & $\mathrm{Fe}_{2} \mathrm{O}_{3}$ & $\mathrm{MnO}$ & $\mathrm{MgO}$ & $\mathrm{CaO}$ & $\mathrm{Na}_{2} \mathrm{O}$ & $\mathrm{K}_{2} \mathrm{O}$ & $\mathrm{F}$ & $\mathrm{Cl}$ & $\begin{array}{c}\mathrm{O}= \\
\mathrm{F} \\
\mathrm{Cl}\end{array}$ & $\mathrm{H}_{2} \mathrm{O}$ & Total & $\begin{array}{c}\text { Molar } \\
\text { composition }\end{array}$ \\
\hline 38 & & 59.90 & 0.41 & 18.94 & 3.27 & NA & 0.15 & 1.11 & 2.43 & 3.78 & 9.02 & NA & NA & & & 99.23 & \\
\hline \multirow[t]{3}{*}{$38 \mathrm{E}$} & $\mathrm{Bt}(2)$ & 34.25 & 4.49 & 13.94 & 9.63 & 2.05 & 0.42 & 13.95 & 0.41 & 0.42 & 9.08 & 1.32 & 0.11 & 0.59 & 3.10 & 90.05 & \\
\hline & San(5) & 62.53 & 0.08 & 18.96 & 0.42 & $\mathrm{NC}$ & 0.07 & 0.16 & 0.79 & 3.01 & 11.63 & 0.24 & 0.01 & & & 97.79 & $\mathrm{Ab}_{27} \mathrm{An}_{4} \mathrm{Or}_{69}$ \\
\hline & $\operatorname{Mt}(3)$ & 0.34 & 5.95 & 0.65 & 32.39 & 51.46 & 1.44 & 0.53 & 0.15 & 0.02 & 0.05 & 0.00 & 0.03 & & & 87.92 & $\mathrm{Mt}_{81} \mathrm{Ulv}_{19}$ \\
\hline \multirow[t]{3}{*}{$38 \mathrm{~F}$} & $\mathrm{Bt}(4)$ & 35.06 & 4.88 & 14.53 & 11.45 & 2.02 & 0.26 & 13.94 & 0.18 & 0.32 & 9.27 & 0.98 & 0.11 & 0.43 & 3.37 & 92.86 & \\
\hline & $\operatorname{San}(6)$ & 62.78 & 0.35 & 19.08 & 0.43 & $\mathrm{NC}$ & 0.06 & 0.06 & 0.66 & 2.69 & 12.00 & 0.12 & 0.02 & & & 98.26 & $\mathrm{Ab}_{25} \mathrm{An}_{3} \mathrm{Or}_{72}$ \\
\hline & $\operatorname{Mt}(3)$ & 0.26 & 8.72 & 0.28 & 36.19 & 46.67 & 0.50 & 0.29 & 0.09 & 0.03 & 0.04 & 0.00 & 0.00 & & & 88.42 & $\mathrm{Mt}_{70} \mathrm{Ulv}_{30}$ \\
\hline \multirow[t]{3}{*}{$38 \mathrm{H}$} & $\mathrm{Bt}(9)$ & 35.65 & 4.69 & 14.44 & 11.90 & 1.79 & 0.26 & 14.66 & 0.21 & 0.36 & 9.12 & 1.51 & 0.10 & 0.65 & 3.18 & 94.62 & \\
\hline & $\operatorname{San}(5)$ & 63.58 & 0.09 & 19.49 & 0.19 & $\mathrm{NC}$ & 0.00 & 0.02 & 1.01 & 3.06 & 11.75 & 0.18 & 0.01 & & & 99.28 & $\mathrm{Ab}_{27} \mathrm{An}_{5} \mathrm{Or}_{68}$ \\
\hline & $\operatorname{Mt}(3)$ & 1.01 & 5.65 & 0.97 & 32.47 & 52.75 & 2.73 & 0.14 & 0.40 & 0.09 & 0.11 & 0.09 & 0.01 & & & 90.92 & $\mathrm{Mt}_{87} \mathrm{Ulv}_{13}$ \\
\hline \multirow[t]{3}{*}{381} & $\mathrm{Bt}(8)$ & 35.25 & 4.64 & 14.45 & 13.39 & 1.67 & 0.20 & 13.81 & 0.02 & 0.48 & 9.36 & 1.04 & 0.11 & 0.47 & 3.37 & 94.27 & \\
\hline & $\operatorname{San}(6)$ & 63.26 & 0.05 & 18.33 & 0.51 & $\mathrm{NC}$ & 0.01 & 0.01 & 0.86 & 2.23 & 12.8 & 0.00 & 0.01 & & & 97.89 & $\mathrm{Ab}_{20} \mathrm{An}_{4} \mathrm{Or}_{76}$ \\
\hline & $\operatorname{Mt}(1)$ & 1.30 & 0.46 & 1.01 & 63.15 & 26.56 & 6.50 & 1.22 & 0.19 & 0.10 & 0.23 & 0.13 & 0.00 & & & 91.81 & $\mathrm{Mt}_{97} \mathrm{Ulv}_{3}$ \\
\hline \multirow[t]{3}{*}{382} & $\mathrm{Bt}(6)$ & 36.40 & 4.58 & 14.17 & 11.29 & 1.93 & 0.36 & 15.00 & 0.00 & 0.44 & 9.41 & 1.46 & 0.10 & 0.64 & 3.22 & 94.95 & \\
\hline & San(3) & 63.12 & 0.07 & 18.70 & 0.45 & $\mathrm{NC}$ & 0.04 & 0.03 & 1.00 & 3.05 & 11.72 & 0.00 & 0.01 & & & 98.20 & $\mathrm{Ab}_{27} \mathrm{An}_{5} \mathrm{Or}_{68}$ \\
\hline & $\operatorname{Mt}(3)$ & 0.20 & 1.41 & 1.17 & 27.94 & 64.16 & 2.35 & 1.03 & 0.07 & 0.01 & 0.11 & 0.48 & 0.00 & & & 92.50 & $\mathrm{Mt}_{96} \mathrm{Ulv}_{4}$ \\
\hline \multirow[t]{3}{*}{383} & $\mathrm{Bt}(1)$ & 38.78 & 4.32 & 14.36 & 10.12 & 2.82 & 0.50 & 15.40 & 0.23 & 0.50 & 9.41 & 2.05 & 0.12 & 0.89 & 3.09 & 98.31 & \\
\hline & San(3) & 63.08 & 0.09 & 18.91 & 0.51 & $\mathrm{NC}$ & 0.04 & 0.03 & 1.18 & 4.64 & 9.14 & 0.03 & 0.02 & & & 97.67 & $\mathrm{Ab}_{41} \mathrm{An}_{6} \mathrm{Or}_{53}$ \\
\hline & $\operatorname{Mt}(5)$ & 0.41 & 1.67 & 1.62 & 28.15 & 62.40 & 2.57 & 0.93 & 0.05 & 0.03 & 0.14 & 0.47 & 0.01 & & & 92.21 & $\mathrm{Mt}_{87} \mathrm{Ulv}_{13}$ \\
\hline \multirow[t]{3}{*}{$38 \mathrm{~V}$} & $\mathrm{Bt}(3)$ & 36.35 & 4.36 & 14.84 & 11.35 & 2.32 & 0.11 & 15.08 & 0.14 & 0.31 & 9.08 & 0.79 & 0.08 & 0.35 & 3.57 & 94.60 & \\
\hline & $\operatorname{San}(6)$ & 63.82 & 0.06 & 19.24 & 0.34 & NC & 0.02 & 0.11 & 0.93 & 4.18 & 9.47 & 0.10 & 0.01 & & & 98.29 & $\mathrm{Ab}_{38} \mathrm{An}_{5} \mathrm{Or}_{57}$ \\
\hline & $\operatorname{Mt}(3)$ & 0.11 & 2.18 & 1.44 & 25.53 & 58.68 & 3.65 & 0.95 & 0.06 & 0.01 & 0.07 & 0.04 & 0.01 & & & 92.45 & $\mathrm{Mt}_{95} \mathrm{Ulv}_{5}$ \\
\hline \multirow[t]{3}{*}{$38 \mathrm{Z}$} & $\mathrm{Bt}(3)$ & 36.26 & 4.18 & 15.29 & 11.14 & 2.68 & 0.18 & 15.05 & 0.12 & 0.31 & 8.87 & 1.48 & 0.09 & 0.64 & 3.25 & 95.40 & \\
\hline & San(4) & 63.65 & 0.06 & 18.88 & 0.22 & $\mathrm{NC}$ & 0.01 & 0.00 & 0.51 & 1.75 & 13.16 & 0.02 & 0.01 & & & 98.27 & $\mathrm{Ab}_{16} \mathrm{An}_{3} \mathrm{Or}_{81}$ \\
\hline & $\operatorname{Mt}(4)$ & 0.10 & 2.80 & 1.67 & 27.39 & 62.50 & 3.39 & 0.55 & 0.15 & 0.02 & 0.06 & 0.01 & 0.00 & & & 92.45 & $\mathrm{Mt}_{93} \mathrm{Ulv}_{7}$ \\
\hline \multirow[t]{3}{*}{ 38P } & $\mathrm{Bt}(1)$ & 35.28 & 4.23 & 15.01 & 12.01 & 3.16 & 0.66 & 13.99 & 0.00 & 0.42 & 8.91 & 0.63 & 0.07 & 0.28 & 3.59 & 94.05 & \\
\hline & San(5) & 63.53 & 0.05 & 19.41 & 0.32 & $\mathrm{NC}$ & 0.01 & 0.01 & 1.11 & 3.33 & 9.81 & 0.07 & 0.00 & & & 97.67 & $\mathrm{Ab}_{32} \mathrm{An}_{6} \mathrm{Or}_{60}$ \\
\hline & $\operatorname{Mt}(3)$ & 0.10 & 2.80 & 1.67 & 31.20 & 55.39 & 2.38 & 1.04 & 0.10 & 0.12 & 0.12 & 0.04 & 0.02 & & & 92.83 & $\mathrm{Mt}_{89} \mathrm{Ulv}_{11}$ \\
\hline \multirow[t]{3}{*}{380} & $\mathrm{Bt}(3)$ & 35.96 & 4.17 & 14.14 & 11.85 & 1.91 & 0.26 & 14.57 & 0.16 & 0.35 & 8.74 & 1.62 & 0.09 & 0.70 & 3.09 & 93.65 & \\
\hline & $\operatorname{San}(7)$ & 63.96 & 0.08 & 19.70 & 0.60 & $\mathrm{NC}$ & 0.02 & 0.08 & 1.16 & 4.10 & 9.18 & 0.06 & 0.01 & & & 98.95 & $\mathrm{Ab}_{38} \mathrm{An}_{6} \mathrm{Or}_{56}$ \\
\hline & $\operatorname{Mt}(4)$ & 0.19 & 5.18 & 3.14 & 32.27 & 54.99 & 2.55 & 0.61 & 0.12 & 0.06 & 0.04 & 0.01 & 0.02 & & & 93.71 & $\mathrm{Mt}_{86} \mathrm{Ulv}_{14}$ \\
\hline \multirow[t]{3}{*}{$38 \mathrm{X}$} & $\mathrm{Bt}(3)$ & 36.85 & 4.35 & 14.70 & 11.48 & 2.46 & 0.23 & 15.07 & 0.08 & 0.70 & 8.94 & 1.50 & 0.12 & 0.66 & 3.25 & 95.93 & \\
\hline & $\operatorname{San}(4)$ & 64.81 & 0.05 & 19.41 & 0.30 & $\mathrm{NC}$ & 0.01 & 0.02 & 0.92 & 2.88 & 10.66 & 0.07 & 0.00 & & & 99.15 & $\mathrm{Ab}_{28} \mathrm{An}_{5} \mathrm{Or}_{67}$ \\
\hline & $\operatorname{Mt}(4)$ & 0.27 & 2.89 & 1.94 & 28.72 & 59.97 & 3.48 & 0.72 & 0.12 & 0.03 & 0.06 & 0.05 & 0.00 & & & 92.29 & $\mathrm{Mt}_{92} \mathrm{Ulv}_{8}$ \\
\hline $38 N$ & $\mathrm{Bt}(4)$ & 36.94 & 4.34 & 14.72 & 11.71 & 2.35 & 0.20 & 15.08 & 0.09 & 0.36 & 9.23 & 1.24 & 0.08 & 0.54 & 3.40 & 96.14 & \\
\hline
\end{tabular}




\begin{tabular}{|c|c|c|c|c|c|c|c|c|c|c|c|c|c|c|c|c|c|}
\hline & San(4) & 64.72 & 0.03 & 20.15 & 0.35 & NC & 0.01 & 0.04 & 1.62 & 3.81 & 9.24 & 0.00 & 0.01 & & & 99.98 & $\mathrm{Ab}_{35} \mathrm{An}_{8} \mathrm{Or}_{56}$ \\
\hline & $\operatorname{Mt}(4)$ & 0.16 & 7.21 & 2.21 & 34.42 & 51.06 & 2.28 & 0.52 & 0.03 & 0.04 & 0.02 & 0.00 & 0.00 & & & 92.68 & $\mathrm{Mt}_{78} \mathrm{Ulv}_{22}$ \\
\hline \multirow[t]{3}{*}{ 38W } & $\mathrm{Bt}(4)$ & 35.89 & 4.32 & 14.18 & 12.61 & 1.80 & 0.33 & 14.58 & 0.10 & 0.34 & 9.02 & 0.95 & 0.11 & 0.42 & 3.43 & 94.08 & \\
\hline & San(4) & 65.44 & 0.06 & 19.24 & 0.32 & NC & 0.01 & 0.00 & 0.77 & 2.51 & 12.18 & 0.00 & 0.01 & & & 100.56 & $\mathrm{Ab}_{23} \mathrm{An}_{4} \mathrm{Or}_{73}$ \\
\hline & $\mathrm{Mt}(4)$ & 0.10 & 4.71 & 2.13 & 31.00 & 55.20 & 1.86 & 1.00 & 0.04 & 0.02 & 0.05 & 0.09 & 0.01 & & & 90.69 & $\mathrm{Mt}_{87} \mathrm{Ulv}_{13}$ \\
\hline \multirow[t]{3}{*}{ 38B } & $\mathrm{Bt}(4)$ & 35.66 & 4.22 & 14.43 & 11.40 & 2.55 & 0.20 & 14.25 & 0.07 & 0.36 & 8.81 & 0.72 & 0.12 & 0.33 & 3.50 & 92.55 & \\
\hline & $\operatorname{San}(4)$ & 63.82 & 0.04 & 18.83 & 0.26 & $\mathrm{NC}$ & 0.03 & 0.01 & 0.91 & 1.94 & 12.78 & 0.04 & 0.01 & & & 98.68 & $\mathrm{Ab}_{18} \mathrm{An}_{5} \mathrm{Or}_{77}$ \\
\hline & $\mathrm{Mt}(4)$ & 0.85 & 4.45 & 2.54 & 32.60 & 55.69 & 1.38 & 0.90 & 0.18 & 0.07 & 0.14 & 0.03 & 0.00 & & & 93.30 & $\mathrm{Mt}_{87} \mathrm{Ulv}_{13}$ \\
\hline \multirow[t]{3}{*}{$38 \mathrm{D}$} & $\mathrm{Bt}(3)$ & 37.9 & 4.00 & 14.57 & 9.42 & 3.47 & 0.39 & 14.07 & 0.15 & 0.64 & 9.33 & 1.67 & 0.08 & 0.74 & 3.17 & 95.35 & \\
\hline & $\operatorname{San}(6)$ & 63.71 & 0.07 & 19.33 & 0.36 & $\mathrm{NC}$ & 0.01 & 0.02 & 1.73 & 3.34 & 10.53 & 0.04 & 0.00 & & & 99.17 & $\mathrm{Ab}_{30} \mathrm{An}_{9} \mathrm{Or}_{63}$ \\
\hline & $\operatorname{Mt}(4)$ & 0.09 & 1.76 & 1.35 & 27.68 & 65.08 & 2.72 & 1.48 & 0.05 & 0.03 & 0.05 & 0.00 & 0.00 & & & 93.83 & $\mathrm{Mt}_{87} \mathrm{Ulv}_{13}$ \\
\hline \multirow[t]{3}{*}{$38 \mathrm{I}$} & $\mathrm{Bt}(3)$ & 35.53 & 4.36 & 14.51 & 10.99 & 2.54 & 0.14 & 14.39 & 0.19 & 0.29 & 8.86 & 0.64 & 0.08 & 0.29 & 3.55 & 92.28 & \\
\hline & $\operatorname{San}(4)$ & 64.30 & 0.05 & 19.12 & 0.49 & NC & 0.00 & 0.10 & 0.56 & 2.08 & 12.92 & 0.12 & 0.01 & & & 99.75 & $\mathrm{Ab}_{19} \mathrm{An}_{3} \mathrm{Or}_{78}$ \\
\hline & $\operatorname{Mt}(5)$ & 2.52 & 3.45 & 2.20 & 25.54 & 63.83 & 1.49 & 0.47 & 0.24 & 0.20 & 0.42 & 0.10 & 0.03 & & & 88.78 & $\mathrm{Mt}_{89} \mathrm{Ulv}_{11}$ \\
\hline \multirow[t]{3}{*}{$38 \mathrm{M}$} & $\mathrm{Bt}(4)$ & 35.47 & 4.27 & 14.04 & 11.82 & 1.91 & 0.21 & 14.65 & 0.13 & 0.31 & 8.95 & 1.42 & 0.10 & 0.62 & 3.16 & 93.10 & \\
\hline & San(4) & 64.15 & 0.06 & 18.81 & 0.28 & NC & 0.02 & 0.01 & 0.66 & 1.88 & 13.23 & 0.05 & 0.00 & & & 99.14 & $\mathrm{Ab}_{17} \mathrm{An}_{3} \mathrm{Or}_{80}$ \\
\hline & $\operatorname{Mt}(4)$ & 0.16 & 4.7 & 2.87 & 31.71 & 56.34 & 2.69 & 0.73 & 0.08 & 0.02 & 0.05 & 0.06 & 0.00 & & & 93.79 & $\mathrm{Mt}_{87} \mathrm{Ulv}_{13}$ \\
\hline \multirow[t]{3}{*}{$38 \mathrm{~T}$} & $\mathrm{Bt}(3)$ & 35.13 & 3.27 & 13.86 & 3.32 & 10.83 & 0.48 & 13.05 & 0.06 & 0.80 & 8.84 & 0.90 & 0.28 & 0.44 & 3.25 & 90.48 & \\
\hline & San(3) & 63.27 & 0.04 & 18.92 & 0.30 & $\mathrm{NC}$ & 0.04 & 0.00 & 0.85 & 2.47 & 11.87 & 0.02 & 0.01 & & & 97.79 & $\mathrm{Ab}_{23} \mathrm{An}_{4} \mathrm{Or}_{73}$ \\
\hline & $\operatorname{Mt}(4)$ & 0.39 & 4.35 & 2.38 & 29.39 & 52.23 & 1.55 & 1.00 & 0.07 & 0.10 & 0.14 & 0.09 & 0.03 & & & 86.47 & $\mathrm{Mt}_{87} \mathrm{Ulv}_{13}$ \\
\hline \multirow[t]{3}{*}{384} & $\mathrm{Bt}(3)$ & 34.01 & 4.65 & 14.35 & 10.91 & 3.04 & 0.26 & 14.48 & 0.11 & 0.58 & 8.76 & 1.61 & 0.22 & 0.73 & 2.99 & 92.66 & \\
\hline & San(3) & 62.64 & 0.05 & 19.21 & 0.34 & $\mathrm{NC}$ & 0.00 & 0.02 & 0.59 & 2.88 & 11.19 & 0.04 & 0.03 & & & 96.98 & $\mathrm{Ab}_{17} \mathrm{An}_{3} \mathrm{Or}_{80}$ \\
\hline & $\operatorname{Mt}(4)$ & 0.13 & 5.99 & 2.59 & 31.69 & 54.28 & 2.15 & 0.88 & 0.04 & 0.27 & 0.07 & 0.02 & 0.02 & & & 92.7 & $\mathrm{Mt}_{87} \mathrm{Ulv}_{13}$ \\
\hline \multirow[t]{3}{*}{385} & $\mathrm{Bt}(4)$ & 33.93 & 4.54 & 13.63 & 11.03 & 2.35 & 0.16 & 15.03 & 0.10 & 0.57 & 8.95 & 1.21 & 0.24 & 0.55 & 3.15 & 91.48 & \\
\hline & $\operatorname{San}(4)$ & 62.23 & 0.06 & 19.07 & 0.32 & NC & 0.01 & 0.01 & 0.78 & 3.08 & 10.67 & 0.01 & 0.02 & & & 96.26 & $\mathrm{Ab}_{29} \mathrm{An}_{4} \mathrm{Or}_{67}$ \\
\hline & $\operatorname{Mt}(3)$ & 0.20 & 4.65 & 2.32 & 30.13 & 54.78 & 2.34 & 0.81 & 0.08 & 0.11 & 0.11 & 0.06 & 0.03 & & & 90.12 & $\mathrm{Mt}_{87} \mathrm{Ulv}_{13}$ \\
\hline \multirow[t]{3}{*}{$38 \mathrm{~A}$} & $\mathrm{Bt}(3)$ & 36.27 & 4.68 & 15.15 & 8.93 & 4.78 & 0.36 & 15.02 & 0.04 & 0.38 & 9.23 & 0.66 & 0.10 & 0.30 & 3.65 & 95.11 & \\
\hline & San(3) & 63.34 & 0.06 & 18.94 & 0.31 & NC & 0.02 & 0.01 & 0.55 & 1.89 & 13.07 & 0.00 & 0.01 & & & 98.18 & $\mathrm{Ab}_{17} \mathrm{An}_{3} \mathrm{Or}_{80}$ \\
\hline & $\operatorname{Mt}(4)$ & 0.09 & 3.55 & 1.73 & 27.53 & 60.50 & 3.84 & 1.78 & 0.03 & 0.03 & 0.06 & 0.00 & 0.01 & & & 93.07 & $\mathrm{Mt}_{91} \mathrm{Ulv}_{9}$ \\
\hline \multirow[t]{3}{*}{3823} & $\mathrm{Bt}(4)$ & 35.67 & 4.59 & 14.35 & 11.58 & 4.64 & 0.22 & 12.78 & 0.01 & 0.47 & 9.15 & 2.06 & 0.06 & 0.89 & 2.89 & 95.11 & \\
\hline & San(8) & 63.76 & 0.08 & 18.59 & 0.56 & NC & 0.04 & 0.10 & 0.56 & 2.97 & 12.18 & 0.43 & 0.02 & & & 99.28 & $\mathrm{Ab}_{26} \mathrm{An}_{3} \mathrm{Or}_{71}$ \\
\hline & $\operatorname{Mt}(2)$ & 0.07 & 5.36 & 4.40 & 33.94 & 54.14 & 0.81 & 1.25 & 0.02 & 0.00 & 0.07 & 0.08 & 0.02 & & & 94.73 & $\mathrm{Mt}_{83} \mathrm{Ulv}_{17}$ \\
\hline \multirow[t]{3}{*}{3824} & $\mathrm{Bt}(4)$ & 35.63 & 4.64 & 14.40 & 10.35 & 3.82 & 0.17 & 14.88 & 0.01 & 0.44 & 9.29 & 1.12 & 0.13 & 0.50 & 3.36 & 94.48 & \\
\hline & San(4) & 64.14 & 0.03 & 18.97 & 0.27 & $\mathrm{NC}$ & 0.03 & 0.00 & 0.67 & 2.73 & 12.28 & 0.04 & 0.03 & & & 99.18 & $\mathrm{Ab}_{24} \mathrm{An}_{3} \mathrm{Or}_{72}$ \\
\hline & $\operatorname{Mt}(6)$ & 0.12 & 6.79 & 3.21 & 34.76 & 51.71 & 1.09 & 0.96 & 0.03 & 0.03 & 0.06 & 0.10 & 0.02 & & & 93.71 & $\mathrm{Mt}_{79} \mathrm{Ulv}_{21}$ \\
\hline $\begin{array}{l}\mathrm{XR} \\
\mathrm{Fe}_{2} \mathrm{O} \\
\text { proce } \\
\mathrm{NC}=\end{array}$ & $\begin{array}{l}\text { onten } \\
\text { ire of } \\
\text { ot calc }\end{array}$ & $\begin{array}{l}\text { mer } \\
\text { ed. }\end{array}$ & 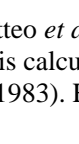 & . & te & 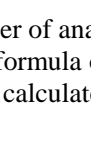 & t & ס & S & - & 4.01 & 1 & 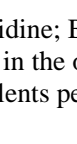 & fo & . & N & $\begin{array}{l}\text { g the } \\
\text { ot analyse }\end{array}$ \\
\hline
\end{tabular}


Table 3. Natural and experimental biotites recalculated on 7 cations - Ti basis. 


\begin{tabular}{|c|c|c|c|c|c|c|c|c|c|c|c|c|c|c|c|c|c|c|c|c|c|c|c|c|}
\hline & 38 & $38 \mathrm{E}$ & $38 \mathrm{~F}$ & $38 \mathrm{H}$ & 381 & 382 & 383 & $38 \mathrm{~V}$ & $38 Z$ & $38 \mathrm{P}$ & 380 & $38 \mathrm{X}$ & $38 \mathrm{~N}$ & $38 W$ & 38B & $38 \mathrm{D}$ & 38I & $38 \mathrm{M}$ & $38 \mathrm{~T}$ & 384 & 385 & $38 \mathrm{~A}$ & 3823 & 3824 \\
\hline $\mathrm{Si}$ & 2.78 & 2.80 & 2.79 & 2.79 & 2.77 & 2.83 & 2.92 & 2.82 & 2.81 & 2.76 & 2.85 & 2.84 & 2.83 & 2.81 & 2.83 & 2.94 & 2.82 & 2.82 & 2.81 & 2.67 & 2.69 & 2.72 & 2.82 & 2.78 \\
\hline $\mathrm{Al}^{\mathrm{IV}}$ & 1.22 & 1.20 & 1.21 & 1.21 & 1.23 & 1.17 & 1.08 & 1.18 & 1.19 & 1.24 & 1.15 & 1.16 & 1.17 & 1.19 & 1.17 & 1.06 & 1.18 & 1.18 & 1.19 & 1.33 & 1.27 & 1.28 & 1.18 & 1.22 \\
\hline $\mathrm{Al}^{\mathrm{VI}}$ & 0.02 & 0.00 & 0.00 & 0.00 & 0.00 & 0.00 & 0.00 & 0.00 & 0.00 & 0.00 & 0.00 & 0.00 & 0.00 & 0.00 & 0.00 & 0.00 & 0.00 & 0.00 & 0.12 & 0.00 & 0.00 & 0.07 & 0.16 & 0.10 \\
\hline $\mathrm{Fe}^{2+}$ & 0.84 & 0.80 & 0.88 & 0.88 & 0.98 & 0.85 & 0.80 & 0.86 & 0.86 & 0.96 & 0.88 & 0.86 & 0.88 & 0.92 & 0.90 & 0.82 & 0.87 & 0.89 & 0.77 & 0.74 & 0.75 & 0.60 & 0.76 & 0.66 \\
\hline${ }^{\mathrm{a}} \mathrm{Fe}^{3+}$ & 0.20 & 0.15 & 0.15 & 0.12 & 0.11 & 0.13 & 0.20 & 0.17 & 0.19 & 0.15 & 0.17 & 0.18 & 0.16 & 0.12 & 0.18 & 0.27 & 0.18 & 0.13 & 0.21 & 0.19 & 0.14 & 0.28 & 0.27 & 0.22 \\
\hline $\mathrm{Mn}$ & 0.02 & 0.03 & 0.02 & 0.02 & 0.01 & 0.02 & 0.03 & 0.01 & 0.01 & 0.04 & 0.02 & 0.02 & 0.01 & 0.02 & 0.01 & 0.03 & 0.01 & 0.01 & 0.03 & 0.02 & 0.01 & 0.02 & 0.01 & 0.01 \\
\hline $\mathrm{Ti}$ & 0.23 & 0.29 & 0.29 & 0.28 & 0.27 & 0.27 & 0.24 & 0.25 & 0.23 & 0.25 & 0.24 & 0.24 & 0.25 & 0.25 & 0.25 & 0.23 & 0.25 & 0.25 & 0.21 & 0.29 & 0.28 & 0.27 & 0.27 & 0.27 \\
\hline $\mathrm{Mg}$ & 1.69 & 1.73 & 1.66 & 1.70 & 1.63 & 1.73 & 1.73 & 1.72 & 1.71 & 1.61 & 1.69 & 1.70 & 1.70 & 1.69 & 1.66 & 1.65 & 1.69 & 1.72 & 1.66 & 1.76 & 1.82 & 1.76 & 1.53 & 1.74 \\
\hline $\mathrm{K}$ & 0.92 & 0.90 & 0.94 & 0.93 & 0.93 & 0.93 & 0.91 & 0.94 & 0.94 & 0.94 & 0.94 & 0.93 & 0.94 & 0.93 & 0.93 & 0.89 & 0.94 & 0.94 & 0.87 & 0.90 & 0.90 & 0.94 & 0.93 & 0.93 \\
\hline $\mathrm{Ca}$ & 0.00 & 0.03 & 0.01 & 0.02 & 0.00 & 0.00 & 0.02 & 0.01 & 0.01 & 0.00 & 0.01 & 0.01 & 0.01 & 0.01 & 0.01 & 0.01 & 0.02 & 0.01 & 0.01 & 0.01 & 0.01 & 0.00 & 0.00 & 0.00 \\
\hline $\mathrm{Na}$ & 0.08 & 0.07 & 0.05 & 0.05 & 0.07 & 0.07 & 0.07 & 0.05 & 0.05 & 0.06 & 0.05 & 0.06 & 0.05 & 0.06 & 0.06 & 0.10 & 0.04 & 0.05 & 0.12 & 0.09 & 0.09 & 0.06 & 0.07 & 0.07 \\
\hline F & 0.38 & 0.33 & 0.24 & 0.36 & 0.25 & 0.35 & 0.48 & 0.19 & 0.35 & 0.15 & 0.39 & 0.36 & 0.29 & 0.23 & 0.18 & 0.41 & 0.16 & 0.36 & 0.23 & 0.40 & 0.30 & 0.16 & 0.50 & 0.27 \\
\hline $\mathrm{OH}$ & 1.62 & 1.67 & 1.76 & 1.64 & 1.75 & 1.65 & 1.52 & 1.81 & 1.65 & 1.85 & 1.61 & 1.64 & 1.71 & 1.77 & 1.82 & 1.59 & 1.84 & 1.64 & 1.77 & 1.60 & 1.70 & 1.84 & 1.50 & 1.73 \\
\hline${ }^{\mathrm{b}} a_{\text {ann }}$ & 0.58 & 0.32 & 0.35 & 0.34 & 0.38 & 0.33 & 0.32 & 0.33 & 0.34 & 0.37 & 0.34 & 0.34 & 0.34 & 0.35 & 0.35 & 0.33 & 0.34 & 0.34 & 0.32 & 0.30 & 0.29 & 0.25 & 0.33 & 0.28 \\
\hline${ }^{\mathrm{c}} a_{\mathrm{ann}}$ & 0.30 & 0.26 & 0.29 & 0.29 & 0.33 & 0.28 & 0.27 & 0.29 & 0.29 & 0.32 & 0.30 & 0.29 & 0.30 & 0.31 & 0.30 & 0.27 & 0.29 & 0.30 & 0.24 & 0.24 & 0.24 & 0.19 & 0.25 & 0.22 \\
\hline${ }^{\mathrm{d}} a_{\text {ann }}$ & 0.01 & 0.01 & 0.02 & 0.01 & 0.02 & 0.01 & 0.01 & 0.02 & 0.01 & 0.02 & 0.01 & 0.01 & 0.02 & 0.02 & 0.02 & 0.01 & 0.02 & 0.02 & 0.01 & 0.01 & 0.01 & 0.00 & 0.01 & 0.01 \\
\hline${ }^{\mathrm{e}} a_{\text {san }}$ & 0.70 & 0.70 & 0.70 & 0.70 & 0.70 & 0.70 & 0.70 & 0.70 & 0.80 & 0.70 & 0.60 & 0.70 & 0.70 & 0.70 & 0.80 & 0.60 & 0.80 & 0.80 & 0.70 & 0.70 & 0.70 & 0.80 & 0.70 & 0.70 \\
\hline${ }^{\mathrm{f}} a_{\mathrm{mt}}$ & 0.85 & 0.85 & 0.87 & 0.84 & 0.95 & 0.93 & 0.93 & 0.92 & 0.90 & 0.87 & 0.86 & 0.89 & 0.85 & 0.85 & 0.85 & 0.85 & 0.87 & 0.86 & 0.84 & 0.83 & 0.84 & 0.88 & 0.85 & 0.84 \\
\hline $\begin{array}{l}\mathrm{b}_{f} \\
\mathrm{H}_{2} \mathrm{O}\end{array}$ & 5129 & 2452 & 2460 & 1851 & 2088 & 2185 & 1955 & 1006 & 2333 & 1272 & 1795 & 2007 & 1823 & 1381 & 2024 & 1495 & 2566 & 1205 & 1836 & 1492 & 1056 & 738 & 3486 & 2871 \\
\hline $\begin{array}{l}{ }^{\mathrm{c}} f \\
\mathrm{H}_{2} \mathrm{O}\end{array}$ & 735 & 741 & 1589 & 1199 & 1351 & 1396 & 1169 & 664 & 1542 & 833 & 1193 & 1328 & 1200 & 938 & 1312 & 804 & 1646 & 815 & 806 & 778 & 618 & 309 & 1490 & 1452 \\
\hline $\begin{array}{l}{ }^{\mathrm{d}} f \\
\mathrm{H}_{2} \mathrm{O}\end{array}$ & 282 & 845 & 1104 & 700 & 917 & 854 & 602 & 473 & 882 & 605 & 656 & 761 & 766 & 637 & 935 & 463 & 1211 & 480 & 535 & 398 & 357 & 219 & 746 & 948 \\
\hline
\end{tabular}


38 = Biotite from Phlegrean Fields trachyte natural sample: the data are calculated from the analyses of Melluso et al. $(1995)$. $f \mathrm{O}_{2}=\mathrm{NNO}+1 \mathrm{in}$ all runs except for: 381 , 382, 383, 3823, 3824 in which $f \mathrm{O}_{2}=$ FMQ. Runs 383 and 3824 performed with a reduced water activity and $f \mathrm{O}_{2}=$ FMQ. Water fugacity $\left(f \mathrm{H}_{2} \mathrm{O}\right)$ was calculated using the relationship of Czamanske \& Wones (1973), the values are expressed in bar.

${ }^{\mathrm{a}} \mathrm{Fe}^{3+}$ is estimated by the method of Dymek (1983).

${ }^{\mathrm{b}}$ Annite activity model of Wones \& Eugster (1965).

cAnnite activity model of Czamanske \& Wones (1973).

${ }^{\mathrm{d}}$ Annite activity model of Bohlen et al.(1980).

${ }^{\mathrm{e}}$ Calculated with the model of Waldbaum \& Thompson (1969).

${ }^{\mathrm{f}}$ Calculated with the model of Woodland \& Wood (1994). 
